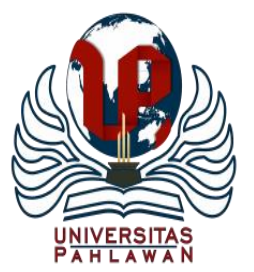

Jurnal Basicedu Volume 4 Nomor 4 Tahun 2020 Halm. 969 - 976

JURNAL BASICEDU

Research \& Learning in Elementary Education

https://jbasic.org/index.php/basicedu/index

\title{
Pendekatan Problem Based Learning (PBL) Terhadap Hasil Belajar Tematik pada Siswa Sekolah Dasar
}

\author{
Fitratul Ilahi $^{1}$, Maria Montessori ${ }^{2}$, Dadan Suryana ${ }^{3}$ \\ Universitas Negeri Padang, Sumatera Barat, Indonesia ${ }^{1,23}$ \\ E-mail: fitratulilahi54@yahoo.com, mariamontesori@ fis.unp.ac.id, suryana@ fip.unp.ac.id
}

\begin{abstract}
Abstrak
Tujuan penelitian ini menggunakan pendekatan kuantitatif dalam bentuk Quasi Eksperimental Design dengan menggunakan bentuk Nonequivalent Control group Design yaitu untuk mengetahui pengaruh pendekatan Problem Based Learning (PBL) dan peserta didik yang diberikan metode konvensional. Populasinya adalah Sekolah Dasar Negeri 13 Kapalo Koto Kota Padang dan sampelnya adalah peserta didik kelas IVA dan IVB sebanyak 57 orang. Pada penelitian ini kelompok eksperimen dan kontrol tidak dipilih secara random karena sampelnya ditentukan dengan teknik purposive sample. Instrumen penelitian terdiri dari (1) instrumen penilaian aspek kognitif, (2) instrumen penilaian aspek afektif, dan (3) lembar observasi aktivitas siswa. Teknik analisa data yaitu (1) analisis aktivitas siswa (2) analisis hasil belajar dengan langkah-langkah uji normalitas, uji homogenitas variansi, dan uji hipotesis. Data penelitian diperoleh tes hasil belajar, hasil penelitian menunjukkan bahwa hasil belajar peserta didik yang diberi pendekatan Problem Based Learning (PBL) lebih tinggi dibandingkan dengan metode konvensional dengan thitung $=1.836<$ ftabel 1.898 .
\end{abstract}

Kata kunci: hasil belajar, problem based learning, pembelajaran tematik

Abstract

The purpose of this study uses a quantitative approach in the form of Quasi Experimental Design by using the Nonequivalent Control group Design that is to determine the effect of the Problem Based Learning (PBL) approach and students who are given conventional methods. The population is Elementary Schools 13 of Kapalo Koto, Padang City and the sample is grade fourth A students and grade fourth B as many as 57 people. In this study the experimental and control groups were not chosen randomly because the sample was determined using a purposive sample technique. The research instrument consisted of (1) cognitive aspects assessment instrument, (2) affective aspect assessment instrument, and (3) student activity observation sheet. Data analysis techniques are (1) analysis of student activities (2) analysis of learning outcomes with the steps of normality test, homogeneity test of variance, and hypothesis testing. The research data obtained by the test of learning outcomes, the results of the study showed that the learning outcomes of students who were given the Problem Based Learning (PBL) approach were higher than those of the conventional method with t count $=1,836<$ ftable 1,898 .

Keywords: learning outcomes, problem based learning, thematic learning

Copyright (C) 2020 Fitratul Ilahi, Maria Montessori, Dadan Suryana

$\square$ Corresponding author :

Address : Air Tawar Padang

ISSN 2580-3735 (Media Cetak)

Email : fitratulilahi54@yahoo.com

ISSN 2580-1147 (Media Online)

Phone : 089531307164

DOI : https://doi.org/10.31004/basicedu.v4i4.490 


\section{PENDAHULUAN}

Perubahan merupakan sesuatu yang harus terjadi pada bidang pendidikan. Perubahan kurikulum yang dilakukan oleh pemerintah dengan tujuan untuk memperbaiki sistem pendidikan (Suwardana, 2018). Dalam rangka menerapkan pendidikan yang bermutu, pemerintah telah menetapkan kurikulum 2013 untuk diterapkan di sekolah/madrasah. Meskipun pada kenyataannya setiap kurikulum pastilah memiliki kekurangan dan perlu dievaluasi serta diperbaiki agar tujuan pendidikan tercapai dengan baik (Bentri, Adree, \& Putra, 2014).

Kurikulum 2013 diharapkan dapat membuat peserta didik aktif, kreatif, dan inovatif serta munculnya pendidikan karakter dan pendidikan budi pekerti dalam diri siswa itu sendiri, hal ini sejalan dengan dengan permendikbud nomor 67 tahun 2013 tentang kurikulum SD, bahwa "Kurikulum 2013 bertujuan untuk mempersiapkan manusia Indonesia agar memiliki kemampuan hidup sebagai pribadi dan warga negara yang beriman, produktif, kreatif, dan afektif serta mampu berkontribusi pada kehidupan bermasyarakat, berbangsa, dan bernegara dan peradaban dunia"(Kemendikbud, 2013).

Pembelajaran yang efektif dan membantu peserta didik dalam membentuk sikap, pengetahuan, dan keterampilannya pada kurikulum 2013 untuk jenjang SD menggunakan pembelajaran tematik terpadu. Pembelajaran tematik sebagai bagian dari pembelajaran terpadu, memiliki prinsip dasar sebagaimana halnya dengan pembelajaran terpadu (Karli, 2016). Pada pembelajaran Tematik Terpadu dimana satu tema dijadikan pemersatu beberapa muatan pembelajaran sekaligus (Vivi, Fitria, Miaz, \& Ahmad, 2020). Pembelajaran Tematik adalah pembelajaran yang berangkat dari suatu tema tertentu sebagai pusat yang digunakan untuk memahami gejala-gejala dan konsep-konsep, baik yang berasal dari muatan pelajaran yang bersangkutan maupun dari muatan pelajaran lainnya (Subandi, 2014).

Pembelajaran tematik terpadu pada kurikulum 2013 dilakukan dengan maksud sebagai upaya untuk memperbaiki dan meningkatkan kualitas pendidikan, terutama untuk mengimbangi padatnya materi kurikulum (Putra, Hadiyanto, \& Zikri, 2020). Di samping itu pembelajaran tematik akan memberi peluang pembelajaran terpadu yang lebih menekankan pada partisipasi/keterlibatan peserta didik dalam belajar. Keterpaduan dalam pembelajaran ini dapat dilihat dari aspek proses atau waktu, aspek kurikulum, dan aspek proses pembelajaran (Mayarnimar \& Taufina, 2017). Pada penyajian materi dalam pembelajaran tematik terpadu, guru harus mampu menyajikan materi dari berbagai mata pelajaran yang ada secara utuh tidak terpisah-pisah dalam sebuah tema yang telah ditentukan. Dengan penyajian materi secara utuh akan mempermudah peserta didik untuk memahami materi pembelajaran.

Hasil belajar adalah kemampuan tertentu baik kognitif, afektif maupun psikomotor yang dicapai atau dikuasai peserta didik setelah mengikuti proses belajar mengajar (Fitri, S, \& Zikri, 2019). Hal ini sesuai dengan hasil belajar PKn dimana mata pelajaran PKn lebih memfokuskan pada afektif untuk membentuk sikap 
peserta didik kearah yang lebih baik, jika peserta didik telah menguasai kogninif maka peserta didik diharapkan mampu untuk membentuk sikap yang ia peroleh dari belajar dan diterapkan dalam kehidupan sehari-harinya (Fitri et al., 2019).

Salah satu faktor yang mempengaruhi hasil belajar adalah aktivitas belajar peserta didik. Menurut KBBI, aktivitas adalah keaktifan, kegiatan, kesibukan sedangkan belajar adalah berusaha memperoleh kepandaian atau ilmu, maka dapat disimpulkan aktivitas belajar adalah kegiatan fisik maupun mental yang dilakukan oleh seseorang untuk memperoleh ilmu atau kepandaian (Ningsih, Miaz, \& Zikri, 2019).

Berdasarkan hasil pengamatan dan wawancara dengan guru kelas IV SD Negeri 13 Kapalo Koto, Bapak Ulil Amri, S.Pd. Pembelajaran yang sudah digunakan hanya pembelajaran tematik yang dilakukan di kelas rendah. Pembelajaran sehari-hari yang digunakan di kelas tinggi adalah pembelajaran konvensional yang banyak menggunakan metode ceramah, tanya jawab, dan penugasan tanpa memperhatikan motivasi belajar peserta didik dalam pembelajaran. Penilaian hasil belajar kognitif pada pembelajaran tematik masih berbentuk bidang studi. Peserta didik kurang terlibat dalam proses pembelajaran, hanya sebagian kecil saja yang menjawab pertanyaan atau yang mengajukan pertanyaan, sedangkan yang lain diam. Sumber belajar yang digunakan masih terfokus pada buku guru dan buku siswa. Kegiatan peserta didik lebih banyak mengisi kolom pertanyaan pada buku siswa, sehingga mereka merasa bosan dan kurang termotivasi untuk belajar yang mengakibatkan hasil belajarnya kurang optimal.

Problem Based Learning merupakan model pembelajaran yang memberikan kebebasan kepada siswa dalam proses pembelajaran, yaitu kebebasan untuk mengeksplorasi pengetahuan yang dimilikinya (Chiang \& Lee, 2016). Model Problem Based Learning siswa diharapkan untuk terlibat dalam proses penelitian yang mengharuskannya untuk mengidentifikasi permasalahan (Noviati, Bentri, \& Zikri, 2020). Problem Based Learning memiliki beberapa kelebihan, diantaranya: (1) meningkatkan motivasi dan aktivitas pembelajaran siswa. (2) membantu siswa dalam mentransfer pengetahuan siswa untuk memahami masalah dunia nyata. (3) membantu siswa untuk mengembangkan pengetahuan barunya dan bertanggung jawab dalam pembelajaran yang mereka lakukan. Disamping itu, PBM dapat mendorong siswa untuk melakukan evaluasi sendiri baik terhadap hasil maupun proses belajarnya. (4) Mengembangkan kemampuan siswa untuk berpikir kritis dan mengembangkan kemampuan mereka untuk menyesuaikan dengan pengetahuan baru. (5) Memberikan kesempatan bagi siswa untuk mengaplikasikan pengetahuan yang mereka miliki dalam dunia nyata (Sada, Mohd, Adnan, \& Yusri, 2016).

Menurut penelitian yang dilakukan Billah (2017) hasil penelitian menunjukkan pada kelas eksperimen hasil belajar siswa tertinggi yaitu 100, sedangkan pada kelas kontrol hasil belajar siswa tertinggi yaitu 95. Berdasarkan pemaparan yang telah dideskripsikan tersebut maka pendekatan 
Problem Based Learning (PBL) dapat mempengaruhi hasil belajar siswa.

\section{METODE}

Penelitian dilakukan pada mata Pelajaran PKn di kelas IV Sekolah Dasar Negeri 13 Kapalo Koto Kota Padang. Penelitian ini direncanakan akan berjalan selama 1 bulan yaitu di bulan Maret pada Kelas IV Semester II Tahun ajaran 2018. Jenis penelitian ini adalah quasy eksperiment dengan rancangan penelitian yang digunakan adalah rancangan penelitian eksperimen dalam bentuk Nonequivalent Control Group Design (Sugiono, 2007). Populasi yang peneliti ambil terdiri dari siswa kelas IV SD Negeri 13 Kapalo Koto yang terdaftar pada semester II tahun ajaran 2017/2018 dapat dilihat pada tabel. Sampel pada penelitian ini yaitu siswa kelas IVa SDN 13 Kapalo Koto sebagai kelas eksperimen kelas IVb sebagai kelas kontrol (Sugiyono, 2014).

Data pada penelitian ini berupa data aktivitas dan hasil belajar peserta didik pada akhir pembelajaran. Data aktivitas peserta didik selama proses pembelajaran di kelas eksperimen dan di kelas kontrol diperoleh melalui pengisian lembar observasi aktivitas peserta didik oleh dua orang observer. Data yang berasal dari lembar observasi aktivitas siswa dan tes hasil belajar lalu dianalisis untuk membuktikan apakah aktivitas dan hasil belajar peserta didik dengan menggunakan model Problem based learning (PBL) lebih tinggi daripada peserta didik dengan model konvensional.

\section{HASIL DAN PEMBAHASAN}

\section{Deskripsi Data Aktivitas Belajar Peserta Didik}

Data mengenai aktivitas belajar peserta didik diperoleh melalui lembar observasi aktivitas peserta didik pada kelas sampel yang disusun berdasarkan indikator aktivitas belajar. Pengamatan observer yang mencatat atau mendata peserta didik yang melakukan aktivitas sesuai dengan indicator yang terdapat pada lembar observasi aktivitas peserta didik.

Tabel 1. Data Hasil Observasi Aktivitas Peserta Didik Kelas Sampel

\begin{tabular}{|c|c|c|c|c|c|}
\hline \multirow{2}{*}{$\begin{array}{c}\text { Kelas } \\
\text { Sampel }\end{array}$} & \multicolumn{4}{|c|}{$\begin{array}{c}\text { Hasil Observasi } \\
\text { Aktivitas }\end{array}$} \\
\cline { 2 - 5 } & $\begin{array}{c}\text { Sangat } \\
\text { Baik }\end{array}$ & Baik & Cukup & $\begin{array}{c}\text { Kuran } \\
\text { g }\end{array}$ & \\
\hline Eksperimen & 0 & 22 & 7 & 0 & 29 \\
\hline Kontrol & 0 & 8 & 20 & 0 & 28 \\
\hline Jumlah & 0 & 30 & 27 & 0 & 57 \\
\hline
\end{tabular}

Berdasarkan tabel di atas, dapat diketahui bahwa aktivitas peserta didik pada kelas eksperimen dan kelas kontrol tergolong pada kategori baik dan cukup. Pada kelas eksperimen aktivitas peserta didik pada kategori baik sebanyak 22 peserta didik dan pada kategori cukup sebanyak 7 peserta didik. Sedangkan pada kelas kontrol aktivitas peserta didik pada kategori baik sebanyak 8 peserta didik dan pada kategori cukup sebanyak 20 peserta didik. Berikut ini akan dijelaskan data nilai rata-rata persentase pada masing-masing indikator aktivitas peserta didik di kelas eksperimen yang diajar menggunakan model Problem Based Learning (PBL) dengan nilai ratarata persentase indikator aktivitas peserta didik yang di kelas eskperimen di ajar menggunakan 
pendekatan konvensional selama penelitian berlangsung.

Berdasarkan hasil penelitian terdapat perbedaan aktivitas belajar peserta didik yang diajar menggunakan model Problem Based Learning (PBL) dengan aktivitas peserta didik yang diajar menggunakan pendekatan konvensional di Kelas IV SD Negeri 13 Kapalo Koto Kecamatan Pauh.

Pengujian hipotesis pertama pada penelitian ini untuk melihat terdapat atau tidaknya perbedaan aktivitas peserta didik yang diajar menggunakan model Problem Based Learning (PBL) dengan aktivitas peserta didik yang diajar menggunakan pendekatan konvensional. Hipotesis mengenai aktivitas peserta didik pada kedua kelas sampel diuji menggunakan statistik non parametrik menggunakan rumus chi kuadrat. Berdasarkan perhitungan diperoleh aktivitas peserta didik setelah dikonversikan tergolong pada kategori baik dan cukup. Aktivitas peserta didik yang diajar menggunakan model Problem Based Learning (PBL) pada kategori baik berjumlah 22 orang peserta didik dan pada kategori cukup berjumlah 7 orang peserta didik sedangkan kategori sangat baik dan kurang berjumlah 0. Aktivitas peserta didik yang diajar menggunakan pendekatan konvensional pada kategori baik berjumlah 8 orang peserta didik dan pada kategori cukup berjumlah 20 orang peserta didik sedangkan pada kategori sangat baik dan kurang berjumlah 0 .

\section{Deskripsi Data Hasil Belajar Peserta Didik Kelas Sampel}

Data hasil belajar peserta didik dari kedua kelas sampel diperoleh setelah tes akhir hasil belajar kedua kelas sampel dilaksanakan, diperoleh data hasil belajar tematik terpadu yang terdiri dari hasil belajar tematik terpadu di kelas eksperimen yang diajar menggunakan model Problem Based Learning (PBL) dan hasil belajar tematik terpadu di kelas kontrol yang diajar menggunakan pendekatan konvensional. Pada kelas eksperimen peserta didik yang mengikuti tes berjumlah 29 orang dan kelas kontrol berjumlah 29 orang. Berdasarkan perhitungan data hasil belajar tematik terpadu di kelas eksperimen dan kelas kontrol yang telah dilakukan, diperoleh gambaran sebagai berikut:

\section{Tabel 2. Hasil Tes Akhir Peserta Didik Kelas Sampel}

\begin{tabular}{|c|c|c|c|}
\hline No & Statistik & $\begin{array}{c}\text { Kelas } \\
\text { eksperimen }\end{array}$ & Kelas kontrol \\
\hline 1 & $\mathrm{~N}$ & 29 & 28 \\
\hline 2 & & 77,93 & 68,00 \\
\hline 3 & Mak & 92 & 84 \\
\hline 4 & Min & 64 & 52 \\
\hline
\end{tabular}

Berdasarkan tabel di atas, dapat diketahui bahwa rata-rata hasil belajar peserta didik kelas eksperimen lebih tinggi dari pada rata-rata hasil belajar peserta didik kelas kontrol. Rata-rata hasil belajar peserta didik kelas eksperimen adalah 77,93 dan rata-rata hasil belajar peserta didik kelas kontrol adalah 68,00 dengan selisih 9,93. Skor maksimal hasil belajar peserta didik di kelas eksperimen adalah 92 dan skor maksimal hasil belajar peserta didik di kelas kontrol adalah 84.Skor minimal hasil belajar peserta didik kelas 
eksperimen adalah 64 dan skor minimal hasil belajar peserta didik kelas kontrol adalah 52 .

Data hasil belajar peserta didik secara keseluruhan di kelas eksperimen dan kontrol yang diperoleh dideskripsikan menurut skor total, skor tertinggi, skor terendah, dan rata-rata masing kelas. Deskripsi data mengenai hasil belajar peserta didik disajikan dalam tabel 3.

Tabel 3. Hasil Tes Akhir Peserta Didik Kelas Sampel

\begin{tabular}{|c|c|c|c|}
\hline No & Statistik & $\begin{array}{c}\text { Kelas } \\
\text { eksperimen }\end{array}$ & Kelas kontrol \\
\hline 1 & N & 29 & 28 \\
\hline 2 & $X$ & 77,93 & 68,00 \\
\hline 3 & Mak & 92 & 84 \\
\hline 4 & Min & 64 & 52 \\
\hline
\end{tabular}

Berdasarkan tabel di atas, dapat diketahui bahwa rata-rata hasil belajar peserta didik kelas eksperimen lebih tinggi dari pada rata-rata hasil belajar peserta didik kelas kontrol. Rata-rata hasil belajar peserta didik kelas eksperimen adalah 77,93 dan rata-rata hasil belajar peserta didik kelas kontrol adalah 68,00 dengan selisih 9,93. Skor maksimal hasil belajar peserta didik di kelas eksperimen adalah 92 dan skor maksimal hasil belajar peserta didik di kelas kontrol adalah 84.Skor minimal hasil belajar peserta didik kelas eksperimen adalah 64 dan skor minimal hasil belajar peserta didik kelas kontrol adalah 52 .

Tabel 4. Hasil Uji Normalitas Data dari Tes Hasil Belajar Peserta Didik Kelas Sampel

\begin{tabular}{|l|l|l|l|l|l|}
\hline Kelas Sampel & $\mathrm{N}$ & $L_{0}$ & $L_{t}$ & $\begin{array}{l}\text { Kesim } \\
\text { pulan }\end{array}$ & Ket \\
\hline
\end{tabular}

\begin{tabular}{|l|l|l|l|l|c|}
\hline Eksperimen & 29 & $\begin{array}{l}0,11 \\
13\end{array}$ & $\begin{array}{l}0,161 \\
4\end{array}$ & $\begin{array}{l}\text { L0 } \\
\square \text { Ltab } \\
\text { el }\end{array}$ & $\begin{array}{c}\text { Data } \\
\text { normal }\end{array}$ \\
\hline Kontrol & 28 & $\begin{array}{l}0,15 \\
95\end{array}$ & $\begin{array}{l}0,164 \\
1\end{array}$ & $\begin{array}{l}\text { L0 } \\
\square \text { Ltab } \\
\text { el }\end{array}$ & $\begin{array}{c}\text { Data } \\
\text { normal }\end{array}$ \\
\hline
\end{tabular}

Dari tabel di atas dapat diketahui bahwa untuk kedua kelas sampel harga $L_{0}<L_{(n, \alpha)}$, dengan demikian dapat disimpulkan bahwa data tes hasil belajar tematik terpadu kedua kelas sampel distribusi normal pada tingkat kepercayaan $95 \%$. Berdasarkan hasil penelitian Terdapat Perbedaan Hasil Belajar Peserta Didik yang Diajar Menggunakan Model Problem Based Learning (PBL) dengan Hasil Belajar Peserta Didik yang Diajar Menggunakan Pendekatan Konvensional di Kelas IV SD Negeri 13 Kapalo Koto Kecamatan Pauh.

Hasil belajar pada kedua kelas dapat dilihat pada tes hasil belajar yang dikerjakan peserta didik secara individu. Berdasarkan hasil analisa data dapat diketahui bahwa rata-rata hasil belajar peserta didik kelas eksperimen lebih tinggi dari pada rata-rata hasil belajar peserta didik kelas kontrol. Rata-rata hasil belajar peserta didik kelas eksperimen adalah 77,93 dan rata-rata hasil belajar peserta didik kelas kontrol adalah 68,00 dengan selisih 9,93. Skor maksimal hasil belajar peserta didik di kelas eksperimen adalah 92 dan skor maksimal hasil belajar peserta didik di kelas kontrol adalah 84. Skor minimal hasil belajar peserta didik kelas eksperimen adalah 64 dan skor minimal hasil belajar peserta didik kelas kontrol adalah 52.

Dengan demikian dapat disimpulkan bahwa terdapat perbedaan hasil belajar peserta didik yang diajar menggunakan model Problem Based 
Learning (PBL) dengan hasil belajar peserta didik yang diajar menggunakan pendekatan konvensional. Tingginya perolehan nilai pada kelas eksperimen dikarenakan pada proses pembelajaran dengan model Problem Based Learning (PBL) diawali dengan pemberian masalah yang autentik dan bermakna kepada peserta didik sehingga peserta didik dapat melakukan penyelidikan dan menyelesaikan masalah secara berkelompok. Berdasarkan perhitungan terdapat perbedaan hasil belajar peserta didik yang diajar menggunakan model Problem Based Learning (PBL) dengan hasil belajar peserta didik yang diajar menggunakan pendekatan konvensional.

\section{KESIMPULAN}

Berdasarkan penelitian yang dilakukan peneliti dapat menyimpulkan beberapa hal, sebagai berikut:

1. Terdapat perbedaan aktivitas peserta didik yang diajar menggunakan model Problem Based Learning (PBL) dengan aktivitas peserta didik yang diajar menggunakan pendekatan konvensional pada pembelajaran tematik terpadu di kelas IV SD Negeri 13 Kapalo Koto Kecamatan Pauh. Dengan demikian model Problem Based Learning (PBL) dapat meningkatkan aktivitas peserta didik.

2. Terdapat perbedaan hasil belajar peserta didik yang diajar menggunakan model Problem Based Learning (PBL) dengan hasil belajar peserta didik yang diajar menggunakan model pembelajaran konvensional pada pembelajaran tematik terpadu di kelas IV SD Negeri 13 Kapalo Koto Kecamatan Pauh.

\section{DAFTAR PUSTAKA}

Bentri, A., Adree, O., \& Putra, A. (2014). Implementasi Kurikulum 2013 di Sumatera Barat. Jurnal Penelitian Pendidikan, 5(1), 88-99. https://doi.org/10.4324/9781315853178

Chiang, C. L., \& Lee, H. (2016). The Effect of Project-Based Learning on Learning Motivation and Problem-Solving Ability of Vocational High School Students. International Journal of Information and Education Technology, 6(9), 709-712. https://doi.org/10.7763/IJIET.2016.V6.779

Fitri, R., S, N., \& Zikri, A. (2019). Pembelajaran Pkn Dengan Model Cooperative Learning Tipe Talking Stick. Jurnal Basicedu, 3(2), 524-532.

Karli, H. (2016). Penerapan Pembelajaran Tematik SD Di Indonesia. EduHumaniora| Jurnal Pendidikan Dasar Kampus Cibiru. https://doi.org/10.17509/eh.v2i1.2752

Kemendikbud. (2013). Implementasi Kurikulum. Permendikbud. https://doi.org/10.1017/CBO9781107415324. 004

Mayarnimar, \& Taufina. (2017). Validity Analysis of the VARK (Visual, Auditory, Read-Write, and Kinesthetic) Model - Based Basic Reading and Writing Instructional Materials for the 1st Grade Students of Elementary School. In Social Science, Education and Humanities Research (Vol. 118, pp. 870874). https://doi.org/10.2991/icset17.2017.141

Ningsih, S. R., Miaz, Y., \& Zikri, A. (2019). Model Discovery Learning Untuk Meningkatkan Aktivitas Dan Hasil Belajar Tematik Terpadu Di Sekolah Dasar. Jurnal Basicedu, 3(2), 524-532.

Noviati, A., Bentri, A., \& Zikri, A. (2020). Pengaruh Penerapan Model Problem Based Learning (Pbl) Terhadap Aktivitas Dan Hasil Belajar Siswa Pada Pembelajaran Tematik Terpadu Di Kelas V Sekolah Dasar. Jurnal 
976 Pendekatan Problem Based Learning (PBL) Terhadap Hasil Belajar Tematik pada Siswa Sekolah Dasar - Fitratul Ilahi, Maria Montessori, Dadan Suryana

DOI: https://doi.org/10.31004/basicedu.v4i4.490

Basicedu, 3(2), 524-532.

https://doi.org/10.31004/basicedu.v4i3.416

Putra, R. A., Hadiyanto, H., \& Zikri, A. (2020). Pengaruh Model Snowball Throwing Terhadap Hasil Belajar Siswa Kelas V Sekolah Dasar. Jurnal Basicedu, 3(2), 524532.

https://doi.org/10.31004/basicedu.v4i3.416

Sada, A. M., Mohd, Z. A., Adnan, A., \& Yusri, K. (2016). Prospects of Problem-Based Learning in Building Critical Thinking Skills among Technical College Students in Nigeria. Mediterranean Journal of Social Sciences, 7(3), 356-365. https://doi.org/10.5901/mjss.2016.v7n3p356

Subandi. (2014). Pengembangan Kurikulum 2013. Jurnal Pendidikan Dan Pembelajaran Dasar.

Sugiono. (2007). Metode Penelitian Kuantitatif, and Pendekatan Kuantitatif. "kualitatif dan $R \& D$. " Bandung: Alfabeta.

Sugiyono. (2014). Populasi dan sampel. Metode Penelitian Kuantitatif, Kualitatif Dan R\&D.

Suwardana, H. (2018). Revolusi Industri 4. 0 Berbasis Revolusi Mental. JATI UNIK: Jurnal Ilmiah Teknik Dan Manajemen Industri.

https://doi.org/10.30737/jatiunik.v1i2.117

Vivi, L., Fitria, Y., Miaz, Y., \& Ahmad, Z. (2020). Pembelajaran IPA Dengan Strategi Pembelajaran Inkuiri Untuk Meningkatkan Keterampilan Proses Sains Dan Motivasi Belajar Siswa di Sekolah Dasar. Jurnal Basicedu. 